\title{
Preliminary Study of Anaerobic Digestion Improvement by Bacterial Immobilization Media from Activated Carbon and Natural Zeolite
}

\author{
Chandra W. Purnomo, Dita P. Sari, Yanisa Laoong-u-thai, and Respati T. Swasono
}

\begin{abstract}
Immobilization on the solid surface of anaerobic microorganism can improve biogas production. A study on the biogas production and the analysis of biogas-producing bacteria in natural zeolite and activated carbon-based media have been carried out. This research was aimed to find out the effect of solid media addition and to identify the bacteria species involved in biogas production under the anaerobic condition. The bacterial culture was carried out in batch anaerobic digesters for a 35-day incubation period. Three different composition of ring-shaped packing consist of natural zeolite $(Z)$, activated carbon (K), and an equal mixture of natural zeolite and activated carbon $(C)$ were added in an anaerobic reactor. Biogas as the product was analyzed with GC-TCD. Each of the bacteria's DNA in the media then isolated, amplified, and also purified to find out the intensity of each DNA band. Sequencing process was conducted for each purified DNA bacteria and the sequence result then translated by BLASTn program in the gene-bank NCBI. The highest methane concentration of $34.32 \%$ was obtained from reactor with natural zeolite media, then the mixed media added reactor provided biogas with $26.31 \%$ methane and the last reactor with activated carbon media showed the smallest value of $20.77 \%$ of methane. Sequencing result shows that Dictyoglomus thermophilum species was dominated on the surface of K-packing, Rhodopseudomonas palustris species was observed on the C-media, and Thermococcus litoralis was living on Z-media. SEM image was taken to confirm the results of DNA identification.
\end{abstract}

Index Terms - Activated carbon, natural zeolite, immobilized media, biogas.

\section{INTRODUCTION}

All Organic waste as by-product of either large scale or small scale industry in Indonesia, which is commonly produced in a mixture of solid and liquid, can be transformed into energy source called biogas, with several treatments. Anaerobic digestion is one of the efficient way to produce biogas from organic waste. Anaerobic microorganisms play an important role in this process which each of them has a different role and character in the anaerobic digestion process

Manuscript received August 15, 2018; revised September 15, 2018.

Chandra W. Purnomo is with the Chemical Engineering Department, Engineering Faculty, also in Agrotechnology Innovation Center (PIAT) Universitas Gadjah Mada, Yogyakarta, Indonesia (e-mail: chandra.purnomo@ugm.ac.id).

Dita P. Sari and Respati T. Swasono are with the Chemistry Department, Faculty of Mathematics and Natural Science, Universitas Gadjah Mada, Yogyakarta, Indonesia (e-mail: \{puspitaditas, respati\}@ugm.ac.id).

Yanisa LAOONG-U-THAI is with the Department of Chemical Engineering, Faculty of Engineering, Burapha University, Chonburi, Thailand (e-mail: yanisa@eng.buu.ac.th).
[1].

Hydrolytic bacteria, acid producing bacteria, and methanogenic bacteria are the main microorganisms lived in the anaerobic reactor [2]. These three groups of bacteria work synergistically during the biogas production. Microorganisms-dependent process in anaerobic digestion resulting in a slow organic waste breakdown which requires a large scale organic waste treatment.

The recent trend in improving biogas efficiency is by adding immobilized media inside the reactor. The media can be in the form of porous or non-porous material with high surface for bacterial attachment. Usually the natural porous materials is preferred due to lower in cost and abundant availability such as natural zeolite and charcoal. By immobilized media addition, the bacterial population inside the anaerobic reactor can be improved and preserved. It also will prevent the biomass washout from the reactor with high loading rate.

In this study, three different media consist of natural zeolite, activated carbon, and bentonite were added to the anaerobic reactor. As the each anaerobic bacteria has a different role during the anaerobic digestion process, a DNA analysis to determine the species that is successfully grown in the media was conducted and followed by Polyacrylamide Gel Electrophoresis system (PAGE). This study aimed to find out the best media and to identify the bacteria species involved in biogas production under the anaerobic condition. It is expected that the anaerobic digestion produce methane as the major gas product with composition above 50\% [3].

\section{EXPERIMENTAL}

Immobilized media used in this study made of natural zeolite and bentonite (1:1), activated carbon and bentonite $(1: 1)$ and natural zeolite, activated carbon, and bentonite $(1: 1: 2)$, then the ID of reactor added with each type of media are $\mathrm{Z}, \mathrm{K}$ and $\mathrm{C}$ respectively. Carboxymethylcellulose (CMC) was added in each media as the plasticizer before extruded, cut into ring shape packing and calcined under inert atmosphere at $600{ }^{\circ} \mathrm{C}$. The media incubated in anaerobic batch reactors $(500 \mathrm{ml})$ for 35 days. Bacteria species in these incubated media were isolated based on Qiagen QIAamp® DNA Mini Kit protocol. The DNA amplification conducted with bacteria primer 357 FGC, 5-CGC CCG CCG CGC GCG GCGGGC GGG GCG GGG GCA CGG GGG GCC TAC GGG AGG CAG CAG-3 and 518R, 5-ATT ACC GCG GCT GCT GG-3 [4]. The DNA bands visualized by PAGE after purified and then sequenced. The composition of biogas from 
each lab-scale anaerobic reactor with different media then analyzed with Gas Chromatography-Thermal Conductivity Detector (GC-TCD).

\section{RESULT AND DISCUSSION}

Gas samples from each lab-scale anaerobic reactor with different media collected after 35 days incubation period. Biogas composition analyzed by GC-TCD and the result showed four similar peaks in each chromatogram (shown in Fig. 1) with retention time of 3.2 minute, 3.5 minute for $\mathrm{CO}$, 5.7 minute for $\mathrm{CH}_{4}$, and 12.2 minute for $\mathrm{CO}_{2}$.

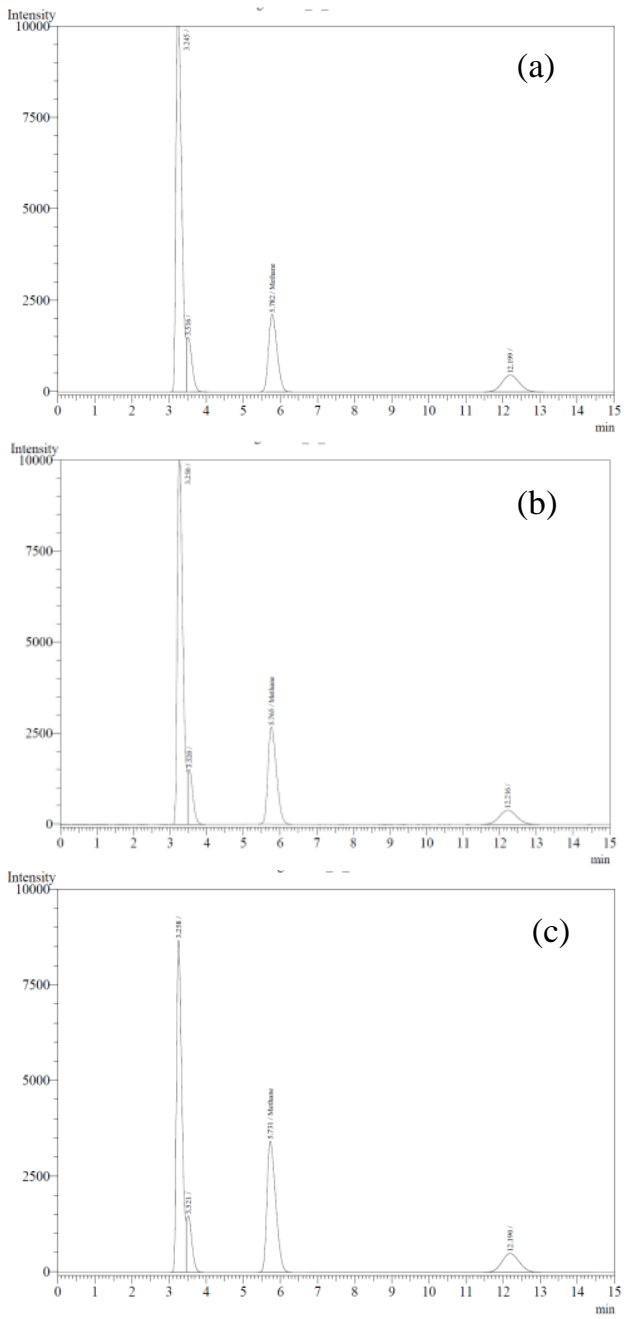

Fig. 1. Chromatogram of biogas product in anaerobic reactor with activated carbon-based (a), mixed activated carbon and zeolite-based (b), and natural zeolite-based (c) media.

Based on the column and detector (TCD) of the GC equipment, each peak estimation leads to the atmosphere, carbon monoxyde, methane, and carbon dioxyde. As shown in Table I, in general the addition of media will enhance the methane formation. The anaerobic reactor with the highest methane concentration was the one with natural zeolite-based media. Natural zeolite-based media has the ion exchanger properties which make this media can either accept or exchange ions and minerals from the reactor's environment into the media [5]. These ions and minerals act as prominent nutrition for bacterial growth. Moreover, the zeolite is also capable in adsorbing inhibitory substances for methane generation such as ammonia [6]. Removing inhibitor will enhance the biogas production and improving methanogen pupulation.

For carbon-based media, the methane concentration is lower than in zeolite. The carbon basically is good for a long run operation while zeolite could give impact in short period of time. It is previously reported that the carbon mobilized media can be used for about 6 months before replacement [7]. It is informed that, carbon addition can enhance the basicity inside the reactor which is good for methanogenic bacteria [7]. However, in a simple anaerobic reactor where the acidogenic and methanogenic process are mixed in the same pot the increase of $\mathrm{pH}$ will not affect so much since the acidogenesis prefer in a low $\mathrm{pH}$ environment. For zeolite, the positive effect of addition of the material can be seen in the two stage processes i.e. acidogenesis and methanogenesis since zeolite addition will not affect the solution $\mathrm{pH}$ [8].

TABLE I: METHANE CONCENTRATION FROM EACH LAB-SCALE AN AEROBIC REACTOR

\begin{tabular}{lll}
\hline $\begin{array}{l}\text { Sample } \\
\text { Code }\end{array}$ & Media Type & Methane Concentration \\
\hline $\mathrm{K}$ & Activated carbon-based & $20,77 \%$ \\
$\mathrm{C}$ & $\begin{array}{l}\text { Mixed activated carbon } \\
\text { and zeolite-based }\end{array}$ & $26,31 \%$ \\
$\mathrm{Z}$ & Natural zeolite-based & $34,32 \%$ \\
Control & - & $18,99 \%$ \\
\hline \hline
\end{tabular}

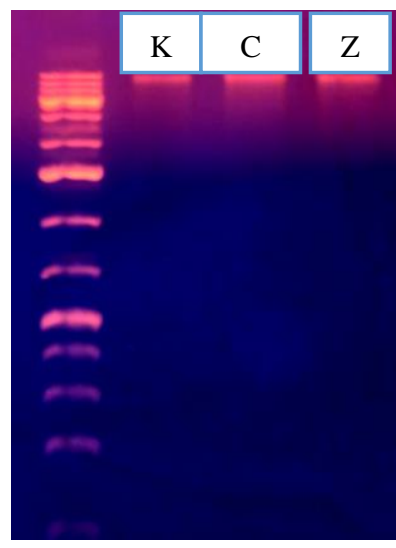

(a)

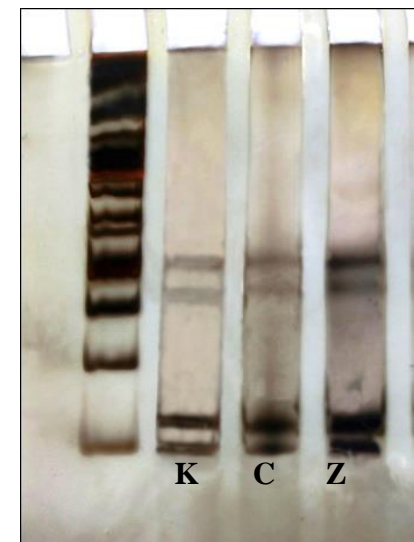

(b)
Fig. 2. Electrophoregram of isolated DNA bands Polyacrylamide Gel Electrophoresis (PAGE) conducted after amplification and purification steps of the isolated DNA (a), Electrophoregram of amplified and purified DNA bands (b).

Z-media has the highest amount of natural zeolite in its composition among all type of media, as high as $50 \%$ which another one only $25 \%$ (C-media). The difference in the natural zeolite composition creates a different pore size of medias which affects their molecular sieve properties. These properties give zeolite an ability to separate a specific gas component from heterogeneous mixture gas by its size (size exclusion) which another components absorbed by the zeolite [9]. Methane, carbon monoxyde, and carbon dioxyde have a different molecule diameter: $0.376 \mathrm{~nm} ; 0.369 \mathrm{~nm}$; and $0.330 \mathrm{~nm}$ respectively [9]. Carbon dioxyde has the smallest diameter that correlates to the smallest intensity of the peak in GC chromatogram which means this gas absorbed by zeolite in a high amount, and vice versa for the methane. Anaerobic reactor with natural zeolite-based media produced the highest 
methane concentration thus methane absorbed by zeolite only in small amount and implies that the higher the amount of natural zeolite in the media, the smaller the pore size.

The DNA of each incubated media then analyzed by agarose gel electrophoresis first to examine whether the DNA isolation was done correctly. Fig. 2.a. shows clear genomic DNA bands in 20,000 bp which belong to all bacterial community in the media. The code $(\mathrm{K}, \mathrm{C}$, and $\mathrm{Z})$ refers to the same media type as written in Table I.

Fig. 2.b. shows characteristic DNA bands in $700 \mathrm{bp}$ from each media sample. Natural zeolite-based media has the highest DNA band intensity which theoretically represents amount of the biogas producing bacteria inside the media. The higher the intensity, the higher the amount of DNA, which means natural zeolite-based media contains the highest biogas producing bacteria colonies qualitatively. These purified DNA then sequenced in 1st BASE Singapore and the nucleotide sequences were translated with ClustalW2 and BLASTn. Table II represents nucleotide sequences of bacteria related to the PAGE bands.

TABLE II: NUCLEOTIDE SEQUENCES OF THE BACTERIA BASED ON THE PAGE BANDS

\begin{tabular}{lcc}
\hline ID & Closely related sequences & Identity (\%) \\
\hline $\mathrm{K}$ & Dictyoglomus thermophilum & 100 \\
$\mathrm{C}$ & Rhodopseudomonas palustris & 100 \\
$\mathrm{Z}$ & Thermococcus litoralis & 92 \\
\hline
\end{tabular}

Both Dictyoglomus thermophilum and Rhodopseudomonas palustris are rod-shaped gram negative bacterias that have a chemoorganotropic properties [10], which handle the organic macromolecules breakdown in the anaerobic digester process [11]. Thermococcus litoralis has the same gram type as both bacterias before, but it exists in a spherical shape which produces $\mathrm{H}_{2} \mathrm{~S}$ as metabolic acid and also $\mathrm{H}_{2}$ [12]. A suitable anaerob and rich in low density organic substrance environment raised up by this acidogenic bacteria, turns the anaerobic reactor into a best place for methanogenic bacteria to live in.

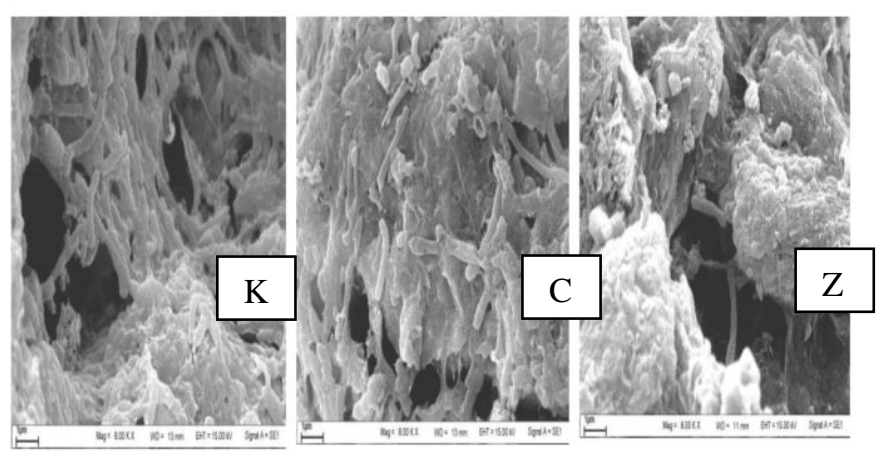

Fig. 3. SEM images of each immobilized media after usage.

Fig. 3 shows rod-shaped object on the surface of $\mathrm{K}$ and $\mathrm{C}$ and ball-shaped object on the $\mathrm{Z}$ media. It is strongly suspected that the objects are microorganism related to biogas production. The SEM images confirm the DNA identification method that Dictyoglomus thermophilum species on K-media and Rhodopseudomonas palustris on $\mathrm{C}$-media are rod shape bacteria while Thermococcus litoralis on Z-media is round-shaped microorganism.

\section{CONCLUSION}

It is found that the highest methane concentration that indicate the better reactor performance was shown by zeolite added media reactor. Meanwhile, the reactor with activated carbon media shows the lowest methane concentration in the produced biogas, while the mixture media was in between. The different dominant microorganism was found for each type of packing which all related to methane formation. It gives a hint that there could be an optimum combination among zeolite and AC packing inside an anaerobic reactor that will produce the highest methane formation.

\section{ACKNOWLEDGMENT}

The research fund PTUPT 2018 from Ministry of Research and Higher Education is greatly appreciated. We also gratefully acknowledge the funding from USAID through SHERA program - Center for Development of Sustainable Region (CDSR).

\section{REFERENCES}

[1] W. Kossmann, U. Ponitz, S. Habermehl, T. Hoerz, P. Kramer, B Klingler, C. Kellner, T. Wittur, F. V. Klopotek, A. Krieg, and H. Euler, Biogas Digest; Federal Republic of Germany: Information and Advisory Service on Appropriate Technology (ISAT), 2007, p. 1.

[2] P. Ozmen and S. Aslanzadeh, "Biogas production from municipal waste mixed with different portions of orange peel," M.Sc. thesis, School of Engineering, University of Boras, 2009.

[3] B. Maynell, "Research of methane in biogass production," J. Sci. Technol, vol. 19, p. 388, 1981.

[4] Y. Ueno, S. Haruta, M. Ishii, and Y. Igarashi, "Changes in product formation and bacterial community by dilution rate on carbohydrate fermentation by methanogenic microflora in continuous flow stirred tank reactor," Appl. Microbiol. Biotechnol., vol. 57, pp. 65-73, 2001.

[5] Z. Milán, P. Villa, E. Sánchez, S. Montalvo, R. Borja, K. Ilangovan, and R. Briones, "Effect of natural and modified zeolite addition on anaerobic digestion of piggery waste," Water Sci. Technol., vol. 48, no. 6, pp. 263-269, 2003.

[6] S. Montalvo, L. Guerrero, R. Borja, E. Sánchez, Z. Milán, I. Cortés, and M. A. Rubia, "Application of natural zeolites in anaerobic digestion processes: A review," App. Clay Sci., vol. 58, pp. 125-133, 2012.

[7] C. Sanchez-Sanchez, A. Gonzalez-Gonzalez, F. Cuadros-Salcedo, F. Cuadros-Blazquez, "Using low-cost porous materials to increase biogas production: A case study in Extremadura (Spain)," J. Cleaner Production., vol. 198, pp. 1165-1172, 2018.

[8] X. Lu, H. Wang, F. Ma, G. Zhao, and S. Wang, "Improved process performance of the acidification phase in a two-stage anaerobic digestion of complex organic waste: Effects of an iron oxidezeolite additive," Bioresource Technol., vol. 262, pp. 169-176, 2018.

[9] S. Sircar and A. L. Myers, Handbook of Zeolite Science and Technology, New York: Marcel Dekker Inc., 2003.

[10] D. A. Coil, J. H. Badger, H. C. Forberger, F. Riggs, R. Madupu, N Fedorova, N. Ward, F. E. E. T. Robb, and J. A. Eisena, "Complete genome sequence of the extreme thermophile dictyoglomus thermophilum H-6-12," Genome Announcements, vol. 2, no. 1, Feb. 2014.

[11] T. S. Farida and D. T. Nurhariyati, "Biofertilisasi bakteri rhizobium pada tanaman kedelai (glycine max (1) merr.)," Berkas Penelitian Hayati, vol. 15, pp. 31-35, 2009.

[12] G. Rakhely, Z. H. Zhou, M. W. W. Adams, and K. L. Kovacs, "Biochemical and molecular characterization of the [NiFe] hydrogenase from the hyperthermophilic archaeon," Eur. J. Biochem., vol. 266 , no. 3 , pp. 1158-1165, 1999.

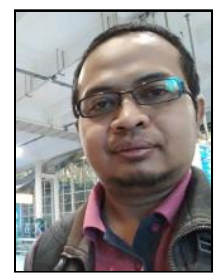

Chandra W. Purnomo was born in March in 1980, he finished his bachelor degree in chemical engineering at UGM, Indonesia. Then, he took masters degree in environmental engineering at UQ, Australia, while the doctoral degree was taken at TITech, Japan.

He works as a lecture and researcher started from his early carrier in Chemical Engineering Department UGM and right now his position is associate professor. He also 
appointed as Deputy Head of Agrotechnology Innovation Center UGM. His current and previous research interests is utilizing solid waste and natural abundant materials for synthesizing advanced functional materials such as adsorbents, slow release media, immobilized media and so on. The last publication in high impact journal was about lithium recovery using adsorption in waste management Vol. 79 (2018).
Dr. Purnomo is the coordinator of ISWF (Indonesian Solid Waste Forum) It is a university forum of solid waste researchers around Indonesia consist of 40 members of higher institutions. Beside that he also appointed as advanced material and sustainable mineral processing group coordinator in Chemical Engineering Department UGM 